\title{
Homesick: Impacts of migratory beekeeping on honey bee (Apis mellifera) pests, pathogens, and colony size
}

\author{
Samantha Ann Alger ${ }^{\text {Corresp., }}{ }^{1}$ ， P. Alexander Burnham ${ }^{1}$ ， Zachary S. Lamas ${ }^{2}$, Alison K. Brody ${ }^{1}$, Leif L. \\ Richardson 3,4 \\ 1 Department of Biology, University of Vermont, Burlington, Vermont, United States \\ 2 Department of Entomology, University of Maryland, College Park, Maryland, United States \\ 3 Rubenstein School of Environment and Natural Resources, University of Vermont, Burlington, Vermont, United States \\ 4 Gund Institute for Environment, University of Vermont, Burlington, Vermont, United States \\ Corresponding Author: Samantha Ann Alger \\ Email address: salger@uvm.edu
}

Honey bees are important pollinators of agricultural crops and the dramatic losses of honey bee colonies have risen to a level of international concern. Potential contributors to such losses include pesticide exposure, lack of floral resources and parasites and pathogens. The damaging effects of all of these may be exacerbated by apicultural practices. To meet the pollination demand of US crops, bees are transported to areas of high pollination demand throughout the year. Compared to stationary colonies, risk of parasitism and infectious disease may be greater for migratory bees than those that remain in a single location, although this has not been experimentally established. Here, we conducted a manipulative experiment to test whether viral pathogen and parasite loads increase as a result of colonies being transported for pollination of a major US crop, California almonds. We also tested if they subsequently transmit those diseases to stationary colonies upon return to their home apiaries. Colonies started with equivalent numbers of bees, however migratory colonies returned with fewer bees compared to stationary colonies and this difference remained one month later. Migratory colonies returned with higher black queen cell virus loads than stationary colonies, but loads were similar between groups one month later. Colonies exposed to migratory bees experienced a greater increase of deformed wing virus prevalence and load compared to the isolated group. The three groups had similar infestations of Varroa mites upon return of the migratory colonies. However, one month later, mite loads in migratory colonies were significantly lower compared to the other groups, possibly because of lower number of host bees. Our study demonstrates that migratory pollination practices has varying health effects for honey bee colonies. Further research is necessary to clarify how migratory pollination practices influence the disease dynamics of honey bee diseases we describe here. 
1

2

3

4 Homesick: impacts of migratory beekeeping on honey bee (Apis mellifera) pests, pathogens, and

5 colony size

6

7 Samantha A. Alger ${ }^{1}$, P. Alexander Burnham ${ }^{1}$, Zachary S. Lamas ${ }^{2}$, Alison K. Brody ${ }^{1}$, Leif L.

8 Richardson ${ }^{3,4}$

9

$10{ }^{1}$ Biology Department, University of Vermont, Burlington, Vermont, United States of America

11 2Department of Entomology, University of Maryland, College Park, Maryland, United States of 12 America

13

$14{ }^{3}$ Rubenstein School of Environment and Natural Resources, University of Vermont, Burlington,

15 Vermont, United States of America

$16{ }^{4}$ Gund Institute for Environment, University of Vermont, Burlington, Vermont, United States of

17 America

18

19 Corresponding author:

20 Samantha A. Alger ${ }^{1}$

21 Email: salger@uvm.edu 


\section{Abstract}

23 Honey bees are important pollinators of agricultural crops and the dramatic losses of honey bee

24 colonies have risen to a level of international concern. Potential contributors to such losses

25 include pesticide exposure, lack of floral resources and parasites and pathogens. The damaging

26 effects of all of these may be exacerbated by apicultural practices. To meet the pollination

27 demand of US crops, bees are transported to areas of high pollination demand throughout the

28 year. Compared to stationary colonies, risk of parasitism and infectious disease may be greater

29 for migratory bees than those that remain in a single location, although this has not been

30 experimentally established. Here, we conducted a manipulative experiment to test whether viral

31 pathogen and parasite loads increase as a result of colonies being transported for pollination of a

32 major US crop, California almonds. We also tested if they subsequently transmit those diseases

33 to stationary colonies upon return to their home apiaries. Colonies started with equivalent

34 numbers of bees, however migratory colonies returned with fewer bees compared to stationary

35 colonies and this difference remained one month later. Migratory colonies returned with higher

36 black queen cell virus loads than stationary colonies, but loads were similar between groups one

37 month later. Colonies exposed to migratory bees experienced a greater increase of deformed

38 wing virus prevalence and load compared to the isolated group. The three groups had similar

39 infestations of Varroa mites upon return of the migratory colonies. However, one month later,

40 mite loads in migratory colonies were significantly lower compared to the other groups, possibly

41 because of lower number of host bees. Our study demonstrates that migratory pollination

42 practices has varying health effects for honey bee colonies. Further research is necessary to 
43 clarify how migratory pollination practices influence the disease dynamics of honey bee diseases

44 we describe here.

\section{Introduction}

Animal-mediated pollination, provided primarily by bees, is required for the production

47

48

49

50

51

52

53

54

55

56

57

58

59

60

61

62

63

64

of $75 \%$ of agricultural food crops (Klein et al., 2007) and provides an estimated annual value of \$200 billion worldwide (Gallai et al., 2009). Managed honey bees (Apis mellifera) are the most important commercially available pollinator and contribute approximately \$17 billion in pollination services revenue annually to the United States (US) alone (Calderone, 2012). However, for over a decade, honey bees have experienced elevated colony losses (Neumann \& Carreck, 2010; Potts et al., 2010; van der Zee et al., 2012, 2013; Kulhanek et al., 2017) attributed to multiple threats including pesticide exposure (Tsvetkov et al., 2017; Woodcock et al., 2017), forage availability (Decourtye, Mader \& Desneux, 2010), and numerous pests and pathogens (vanEngelsdorp \& Meixner, 2010). The numerous threats affecting honeybees may be exacerbated by practices inherent to the apicultural industry and required for large-scale crop pollination, specifically migratory beekeeping (Royce \& Rossignol, 1990; Traynor et al., 2016a). To meet the pollination demand of a variety of US agricultural crops, large numbers of bees are moved among crops at regional and national scales. Conditions for migratory colonies vary greatly depending on the distance traveled and the crops visited. In the most extreme cases, colonies are transported by truck to a series of monoculture crops including blueberries, cranberries, almonds, and citrus (VanEngelsdorp et al., 2013) for months at a time. At each stop along the journey, millions of bees from different origins converge on a single crop for the duration of bloom, which typically lasts approximately one month and may offer little forage 
65 diversity (Decourtye, Mader \& Desneux, 2010; Colwell et al., 2017). Nectar, comprised of 66 sugars and amino acids, is required to fuel flight and feed the colony while pollen, high in 67 protein and fats, provisions developing brood (Brodschneider \& Crailsheim, 2010a). To ensure 68 survival en route or when crops are not in bloom, colonies may be supplemented with sucrose 69 syrup and artificial pollen, temporary but poor substitutes for the diverse array of nectar and 70 pollen types bees obtain in natural landscapes (Huang, 2012). Thus, compared to their stationary 71 counterparts, migratory colonies experience greater stress (Simone-Finstrom et al., 2016), greater 72 exposure to pesticides (Mullin et al., 2010; Traynor et al., 2016a), and lower quality forage 73 (Brodschneider \& Crailsheim, 2010b; Decourtye, Mader \& Desneux, 2010; Colwell et al., 2017), 74 all of which may increase susceptibility to disease (Di Pasquale et al., 2013; Sánchez-Bayo et al., 75 2016). It is well known that stress from long distance travel results in heightened bacterial and 76 viral infections in vertebrate livestock (Yates, 1982). However, despite the importance of large77 scale pollination events for agriculture, few studies have examined how migratory conditions

78

may contribute to disease incidence in bees (Welch et al., 2009; Zhu, Zhou \& Huang, 2014;

Traynor et al., 2016b).

In the US, there are an estimated 2.62 million commercial honey bee colonies of which over half are contracted for crop pollination (USDA National Agricultural Statistics Service, 2017b). California almond pollination is the largest annual event for the migratory beekeeping industry, requiring over 1.5 million honey bee colonies (USDA National Agricultural Statistics Service, 2017a). It is the largest convergence of honey bee colonies in the US, providing conditions in which pathogens are likely to be introduced, transmitted, and subsequently spread as colonies move along their human-imposed migration route (Bakonyi et al., 2002; Welch et al., 2009; Runckel et al., 2011; Goulson et al., 2015). Each acre of almonds requires an average of 
88 two honey bee colonies (Carman, 2011) and as bees will forage $3 \mathrm{~km}$ from their colonies

89 (Visscher \& Seeley, 1982; Beekman \& Ratnieks, 2000; Couvillon et al., 2015), bees in large

90 orchards could theoretically share flowers with bees from nearly 56,000 other colonies. While

91 almond flowers may produce a large quantity of nectar and pollen, there is evidence that it is

92 relatively low quality (and possibly toxic) forage for honey bees (London-Shafir, Shafir \&

93 Eisikowitch, 2003; Kevan \& Ebert, 2005); moreover, the vast fields provide little forage

94 diversity for bees and are heavily sprayed with pesticides (California Department of Pesticide

95 Regulation, 2017), exposing bees to additional stress.

96 The spread of the most devastating honey bee parasites and pathogens has mainly

97 occurred as a result of transporting honey bees long distances. For example, the Varroa mite

98 (Varroa destructor), an ectoparasite and known vector of numerous RNA viruses, became a

99 major contributor to colony losses in both North America and Europe after its introduction from

100 Asia (Rosenkranz, Aumeier \& Ziegelmann, 2010; Nazzi et al., 2012). Nosema ceranae, a

101 microsporidian implicated in high colony mortality in Spain (Higes et al., 2008), has also

102 reached high frequencies since its introduction from Asia to the Americas and Europe (Klee et

103 al., 2007; Chen et al., 2008). Despite the role of long-distance travel in disease spread, there is a

104 surprising lack of studies examining the role of migratory beekeeping in disease spread.

105 A limited number of observational surveys have compared disease loads of colonies

106 belonging to migratory and stationary operations and found a higher prevalence of some

107 pathogens in migratory colonies (Traynor et al., 2016b) including Nosema ceranae (Zhu, Zhou \&

108 Huang, 2014) and RNA viruses (Welch et al., 2009), some of which were not previously

109 described in honey bees (Runckel et al., 2011). However, the focus of previous studies has been

110 the collection of baseline disease data to characterize diseases in migratory colonies and, as such, 
111 rarely control for migratory conditions, management practices, and sampling times, all of which

112 can significantly affect disease loads and colony health (Runckel et al., 2011; Glenny et al.,

113 2017). Furthermore, studies examining the impact of migratory conditions on bees rarely include

114 a control group of stationary colonies for comparison (but see Zhu, Zhou \& Huang, 2014;

115 Simone-Finstrom et al., 2016). Although migratory honey bee colonies are implicated as disease

116 sources and could serve to introduce disease to local stationary honey bee colonies (Welch et al.,

117 2009) we are unaware of previous studies that explicitly test the role of migratory colonies in the

118 spread of diseases or parasites. Here, we conducted a two-pronged experiment in which we

119 controlled for migratory conditions, sampling time, and beekeeper management practices. We

120 first tested the effects of migration on honey bee colony population size, Varroa mite parasites,

121 and pathogens including Nosema (a microsporidian) and three RNA viruses: black queen cell

122 virus (BQCV), deformed wing virus (DWV), and Israeli acute paralysis virus (IAPV). We

123 examined differences in the parasite and pathogen prevalence and load as well as colony size of

124 migratory and stationary colonies. Second, we examined if there is evidence for the transmission

125 of diseases from migratory colonies to stationary colonies. If migration exposes bees to stressors

126 that increase disease susceptibility, we predicted that migratory colonies would have greater

127 pathogen prevalence and loads when compared to their stationary counterparts, and that

128 pathogen loads in sympatric stationary colonies would increase after foraging alongside the

129 migratory colonies for one month.

130 Materials and Methods

In February 2017, we selected 48 colonies from a North Carolina apiary that is used for

132 the production of products (honey, colonies, etc.) rather than pollination services, and assigned

133 each to one of the following groups: migratory $(\mathrm{n}=16)$, isolated stationary (isolated $)(\mathrm{n}=16)$, and 
134 exposed stationary (exposed) ( $\mathrm{n}=16$; Fig. 1$)$. We transported colonies in the migratory group

135 from Whiteville (Columbus County), North Carolina to Coalinga (Fresno County), California

$136\left(36^{\circ} 21^{\prime} \mathrm{N}, 120^{\circ} 12^{\prime} \mathrm{W}\right)$ to pollinate almonds for the duration of the bloom (approximately one

137 month). They were then transported back to North Carolina. As typical of migratory beekeeping

138 practices, the migratory colonies were covered by netting during transport (to reduce escapees)

139 and temporarily brought to a nearby holding yard in California before and after pollinating

140 almond orchards. The isolated stationary group remained in North Carolina $\left(34^{\circ} 22^{\prime} \mathrm{N}, 78^{\circ} 36^{\prime} \mathrm{W}\right)$

141 and outside the flight distance from returning migratory colonies for the entirety of the

142 experiment. To maintain similar colony densities at the isolated stationary and migratory yards,

143 there were an additional 15 stationary colonies in the isolated yard. These colonies originated

144 from the same North Carolina apiary and were not tested as part of the experiment.

145 At the start of the experiment in February 2017, all colonies had 7-9 frames of bees, and

146 7-8 frames with brood. To measure bee population size, we counted frames of adult bees (FOB)

147 by assessing the coverage of adult bees on each frame and summing the estimates for all frames

148 in the brood chamber (the lower hive body containing the queen and brood) (DeGrandi-Hoffman

149 et al., 2016). Frames with brood were assessed by counting the total number of frames containing

$15030 \%$ capped brood. Each colony was provided a new queen by replacement with open-mated

151 Italian (A. mellifera ligustica)/Carniolan (A. mellifera carnica) queens in summer 2016.

152 Colonies were matched in triplicate by frames of bees and frames of brood and randomly

153 assigned a treatment group (migratory, isolated stationary, or exposed stationary) to ensure equal

154 distribution across groups. Prior to the start of the experiment, in October 2016, we treated all

155 colonies for Varroa mites with fluvalinate, a synthetic pyrethroid commonly used as an acaricide

156 in honey bee colonies. No other mite or pathogen treatments were used for the duration of the 
157 experiment. To ensure that colonies would persist for the duration of the experiment, we

158 provided supplemental feed to all colonies (in all treatment groups) on two occasions: pollen

159 substitute prior to shipping the migratory colonies to California and upon return, $5 \mathrm{lbs}$. of fondant

160 (sucrose and water stabilized with gelatin). As colonies grew during the duration of the study,

161 additional hive bodies were added as needed to prevent swarming.

162 We compared bee population size and disease loads in the migratory and isolated

163 stationary group three times: before the migratory group departed for California (Jan. 25),

164 immediately after the migratory group returned to North Carolina from California (Feb. 28), and

165 one month later (March 25). To test for disease spread from the migratory colonies to their

166 stationary counterparts, we monitored the third group of colonies, the exposed stationary group,

167 which remained in North Carolina but shared a yard with the migratory colonies once they

168 returned from California $\left(34^{\circ} 11^{\prime} \mathrm{N}, 78^{\circ} 46^{\prime} \mathrm{W}\right)$. We assessed bee population size and disease loads

169 in the exposed stationary group twice: once before sharing a yard with the migratory group (Feb.

170 28), and again approximately one month after residing with the migratory colonies in the same

171 yard (March 25). Land cover surrounding each of the North Carolina yarding areas were

172 dominated by crops, mixed forest, and woody wetlands, and we expect that colonies in the two

173 sites had similar access to early spring floral resources. Hives were housed on private land and

174 permission was granted by the owners.

175 At each sampling event, we inspected all colonies for brood diseases, measured colony

176 size, and collected bees for pathogen analyses. To estimate colony size, we measured frames of

177 bees (FOB) as before (DeGrandi-Hoffman et al., 2016). We also recorded the queen status of

178 each colony (queen-right, queenless, queen cells present, or drone-laying queen). We collected

179 live bees from the brood chamber to detect and quantify the following parasites and pathogens: 
180 Varroa, Nosema, BQCV, DWV, and IAPV. To quantify Varroa and Nosema spp., we collected

181 approximately 300 bees from the brood chamber and transferred them to ethanol. To quantify

182 virus prevalence and load, we collected an additional 150 bees from the brood chamber. These

183 samples were stored and shipped to Vermont on dry ice and transferred to $-80^{\circ} \mathrm{C}$ for storage prior

184 to analysis.

185 To examine differences in climate and weather conditions experienced by the migratory

186 and stationary groups, we used publicly available NOAA local climatology data collected by

187 weather stations nearest to our field sites (NOAA National Centers for Environmental

188 Information) (Table S1).

\section{Varroa mite and Nosema spp. quantification}

To calculate the number of Varroa mites per 100 bees, ethanol samples were agitated for

19160 seconds, strained through hardware cloth to separate the mites from the bees, and all mites

192 and bees were counted (Lee et al., 2010). We conducted spore counts to quantify Nosema spp.

193 Although our methods did not differentiate between the two species of Nosema, (N. apis and N.

194 ceranae) previous work has found $N$. ceranae to be the predominant species in many regions

195 (Klee et al., 2007; Chen et al., 2008; Williams et al., 2008, 2014). To conduct spore counts, we

196 transferred 100 bees from the ethanol sample to a plastic bag and pulverized them using a pestle

197 on the outside of the bag for 90 seconds. We then added $100 \mathrm{~mL}$ of distilled water, allowed it to

198 settle for 45 seconds, and transferred $10 \mu \mathrm{L}$ onto a haemocytometer counting chamber. We

199 counted spores for each sample twice under 40X magnification, averaged them, and converted to 200 spores/bee (Fries et al., 2013).

201 Virus quantification 
203 nitrogen and homogenized them in an extraction bag with $10 \mathrm{~mL}$ of GITC buffer using protocols

204 established by USDA-ARS Bee Research Lab Beltsville, MD (Evans, 2006). We followed

205 EZNA Plant RNA Standard Protocols (Omega Bio-Tek) with $100 \mu \mathrm{L}$ of the resulting

206 homogenate thereafter. Using a Spectrometer (Nanodrop, Thermo Scientific), we assessed all

207 RNA quantity and quality and diluted all RNA extractions to $20 \mathrm{ng} / \mu \mathrm{L}$ prior to virus assays.

208 For reverse transcription of RNA and absolute quantification, we performed duplicate

209 reverse transcription quantitative polymerase chain reaction (RT-qPCR) for each sample with a

210 SYBR green one-step RT-qPCR kit in $10 \mu \mathrm{L}$ reactions using the following thermal cycling

211 program: $10 \mathrm{~min}$ at $50^{\circ} \mathrm{C}(\mathrm{RT})$ followed by $1 \mathrm{~min}$ at $95^{\circ} \mathrm{C}$, and 40 amplification cycles of $95^{\circ} \mathrm{C}$

212 for $15 \mathrm{~s}, 60^{\circ} \mathrm{C}$ for $60 \mathrm{~s}$. Lastly, we obtained the melt-curve starting at $65-95^{\circ} \mathrm{C}\left(0.5^{\circ} \mathrm{C}\right.$ increments,

213 each 2 seconds). We used primers specific to the positive strand of the following RNA virus

214 targets: BQCV, DWV and IAPV, and a housekeeping gene (Actin) as a positive control of RNA

215 extraction efficiency (Table S2). We calculated quantification using duplicate standard curves of

216 gBlocks Gene Fragments (Integrated DNA Technologies; Data S1) that were developed using

217 double-stranded, sequence verified genomic blocks consisting of the four targets of interest

218 separated by ten random base pairs. Sequences of random base pairs consisting of at least $50 \% \mathrm{G}$

219 and Cs were used at the beginning and terminal ends of the fragment. Efficiencies were 95.21\%

220 (BQCV), 91.06\% (DWV), 90.27\% (IAPV), and 90.12\% (Actin), with correlation coefficients

221 ( $\left.\mathrm{R}^{2}\right)$ ranging from 0.993-0.999. To verify RT-PCR analyses, sequences with lengths of 100-130

222 bps were generated through DNA sequencing performed in the Vermont Integrative Genomics

223 Resource using a 3130xl Genetic Analyzer.

\section{Data reporting}


We use "pathogen prevalence" to refer to the percentage of colonies positive for a

226 pathogen (Varroa, Nosema, BQCV and DWV). In addition to presence/absence data, we

227 investigated the severity of infection by quantifying each pathogen - we refer to this as

228 "pathogen load". Virus load (BQCV and DWV) results for each colony are presented in average

229 virus genome copies/bee. We did not detect IAPV in our experimental colonies and it was

230 therefore excluded from further analysis. We report Varroa as the number of mites per 100 bees

231 and Nosema as average number of spores/bee.

232

233 Data analysis and statistics

234 Before analyzing, we checked all response variables for normality using Shapiro-Wilk

235 tests. To improve normality, Varroa and Nosema loads as well as BQCV and DWV loads

236 (genome copies per bee) were $\log +1$ transformed. To establish that there were no differences

237 between treatment groups at the outset, we analyzed all variables at the initial time step using

238 ANOVAs for continuous variables (FOB, load of Varroa, Nosema, BQCV, and DWV) and Chi-

239 Square tests of independence for binary variables (prevalence of Varroa, Nosema, BQCV, and

240 DWV).

241 To test whether the full suite of response variables collectively predicted colony

242 treatment membership, we conducted classification analyses for Experiments 1 (migratory vs.

243 stationary) and 2 (exposed vs. isolated) using linear combinations based on all response variables

244 (except BQCV prevalence as it was fixed at 100\% prevalence for all groups and as such caused

245 model fitting failures). To examine how groups differed after experimental manipulation, we

246 used data from sampling events two and three for Experiments 1 and 2, respectively. The models

247 were trained using a conservative cross validation approach to reduce over-fitting the model to 
248 our data. We tested for differences between groups' centroids in multivariate space for each time

249 point with PERMANOVA, a non-parametric MANOVA, using Euclidian distance-based

250 dissimilarity matrices. To visualize between-group separation, the centered values from linear

251 discriminate functions (LD1 and LD2) were plotted for each colony.

252 To test the effect of treatment and time on prevalence, we analyzed all pathogens

253 (Nosema, Varroa, BQCV, and DWV) using separate generalized linear mixed effects models

254 (GLMMs) using the binomial (link="logit") distribution family. For measures of pathogen load,

255 and FOB, we used linear mixed effects models (Harrison et al., 2018). All models used the same

256 repeated measures design. Treatment, sampling event, and their interaction were included as

257 fixed effects in order to determine how each dependent variable was affected by our

258 manipulation through time. Colony and bee yard were included as random effects in order to

259 determine the among colony variance within each treatment and account for potential differences

260 between bee yards. To examine how the Varroa load of migratory and stationary colonies

261 differed over time with respect to FOB, we conducted a separate linear mixed effects model. We

262 first tested for temporal autocorrelation in the residuals of the model using an ACF plot and no

263 autocorrelation was detected. For this model, we used FOB, treatment, time, and the resultant

264 interactions as fixed effects and colony as a random effect. Significance for all models was

265 determined using Type II Wald Chi-Square tests.

266 To examine potential differences in climate between California and North Carolina

267 during the 27 days the migratory bees were in California, we used one-way Analysis of Variance

268 (ANOVAs) on average daily temperature, precipitation, and wind speed by state (NOAA

269 National Centers for Environmental Information). 
We conducted all statistical analyses using the statistical software "R" (R version 3.3.1).

271 GLMMs were conducted using the lme4 package (v 1.1-13) (Bates et al., 2015). The

272 corresponding Type II Wald Chi-Square tests were conducted using the Anova function in the

273 car package (v 2.1-4) (Fox \& Weisberg, 2011). Temporal autocorrelation was tested using the

274 acf function. Classification analyses were conducted using the lda function in the mass package

275 (v 7.3-45) (Ripley \& Venables, 2002). The adonis function was used to perform PERMANOVA

276 in the vegan package (v 2.4-3) (Oksanen et al., 2017).

\section{Results}

While in California, migratory colonies experienced similar weather conditions (mean

279 daytime temperature, wind speed, and precipitation) to those experienced by stationary colonies

280 in North Carolina $\left(\mathrm{F}_{1,52}<3.106, \mathrm{P}>0.084\right.$; Table $\left.\mathrm{S} 1\right)$. All colonies were absent of IAPV. BQCV

281 was present in all colonies for the duration of the study (Fig. S1).

282

283

\section{Experiment 1: Migratory verses Stationary}

At the start of the experiment, there was no significant difference between migratory and stationary colonies in prevalence $\left(\chi_{1}^{2}<1.143, \mathrm{P}>0.285\right)$ or load $\left(\mathrm{F}_{1,30}<3.01, \mathrm{P}>0.093\right)$ of any

285

286

287

288

289

290

291

292

of the four pathogens. In addition, there was no difference in FOB at the beginning of the experiment (migratory: $7.94 \pm 0.57 \mathrm{sd}$, stationary: $7.44 \pm 0.51 \mathrm{sd}$ ).

Upon the return of the migratory colonies, our pathogen and hive population measurements collectively predicted whether a colony was migratory or stationary (Fig. 2A). The linear combination (LD1) adequately discriminated between the migratory group and the stationary group and yielded correct classification rates of $87.5 \%$ for migratory colonies and $75 \%$ for stationary colonies. Also, prior to contact with the migratory colonies, the exposed colonies were similar to the isolated stationary colonies and essentially formed one large group (Fig 2A). 
293 After contact with migratory colonies, there was statistically significant group separation

294 between migratory and stationary treatments $\left(\mathrm{F}_{1,30}=5.03, \mathrm{P}=0.007\right)$.

295 Migratory colonies returned from California with significantly higher BQCV loads

296 compared to the stationary group $\left(\chi_{1}^{2}=16.488, \mathrm{P}<0.001\right.$; Fig $\left.3 \mathrm{~A}\right)$, and BQCV load increased

297 with time (Fig. 3A and Table 1). The prevalence (Fig. S1) and load of DWV (Fig 3B) did not

298 differ between treatments following return of migratory colonies but both increased with time

299 (Table 1). Nosema load and prevalence (Fig. S1) did not differ between treatments following

300 return of migratory colonies and Nosema load decreased with time (Table 1). However, for

301 Varroa, there was a significant treatment $\times$ time interaction (Fig 3C). Varroa loads increased

302 steadily for stationary colonies, but decreased in migratory colonies over the month after

303 returning from California $\left(\chi_{1}^{2}=6.465, \mathrm{P}=0.011\right)$. There was also a significant interaction of

304 treatment $\times$ time for FOB, with migratory colonies returning with fewer FOB than their

305 stationary counterparts $\left(\chi_{1}^{2}=5.651, \mathrm{P}=0.017\right)$. There was a significant interaction of FOB $\times$

306 treatment $\times$ time on Varroa loads $\left(\chi_{1}{ }^{2}=4.045, \mathrm{P}=0.044\right)$ indicating that Varroa loads were

307 differentially affected by FOB for each treatment group over time. Other interaction terms were 308 not statistically significant (Table 1).

\section{Experiment 2: Exposed verses Isolated}

At sampling event two, there was no significant difference between exposed and isolated

311 stationary colonies in pathogen prevalence $\left(\chi_{1}^{2}<1.143, \mathrm{P}<0.285\right)$ or load $\left(\mathrm{F}_{1,30}<1.279, \mathrm{P}>\right.$

$3120.267)$. FOB was similar between groups at the beginning of the experiment $\left(\mathrm{F}_{1,29}=0.858, \mathrm{P}=\right.$ $3130.362)$.

314 One month after the exposed group foraged alongside the migratory colonies, there was 
315 an increase in between-group separation with groups becoming more distinguishable from each

316 other. While all groups separated in this third time step, the exposed and migratory groups were

317 less distinguishable from one another compared to the stationary group (Fig. 2B). The linear

318 combinations (LD1 and LD2) yielded a correct classification rate of $75 \%$ for stationary colonies

319 but correct classification rates for migratory and exposed colonies were lower, $43.75 \%$ and

$32056.25 \%$, respectively. PERMANOVA results indicated statistically significant group separation

321 between isolated, migratory and exposed treatments $\left(\mathrm{F}_{2,43}=4.72, \mathrm{P}=0.001\right)$.

322 We found no effects of treatment (exposed verses isolated) for any of the parasite or

323 disease response variables (Fig 3). However, Varroa prevalence and load, Nosema prevalence

324 and load, and BQCV significantly increased with time (Table 2). There was a significant

325 treatment $\times$ time interaction for both DWV load $\left(\chi_{1}^{2}=9.229, \mathrm{P}=0.002\right.$; Fig 3B $)$ and DWV

326 prevalence $\left(\chi_{1}^{2}=4.94, \mathrm{P}=0.026\right.$; Fig. S1 $)$ such that DWV in exposed colonies increased at

327 significantly higher rates than the isolated group. There was also a significant treatment $\times$ time

328 interaction for FOB $\left(\chi_{1}^{2}=9.946, \mathrm{P}=0.0016\right.$; Fig 3D) with exposed bees increasing at a

329 significantly higher rate compared to the isolated group. Other interaction terms were not

330 significant (Table 2).

\section{Discussion}

Migratory pollination services are an essential component of the US agricultural

333 economy, yet this practice exposes honey bee colonies to a combination of factors that may

334 compromise individual bee and colony health. Although there is widespread concern that

335 migratory pollination can place honey bee colonies at increased risk to acquire and spread

336 pathogens and parasites, there is a lack of experimental evidence demonstrating this

337 phenomenon. Here, we controlled for management practices and starting conditions as well as 
338 the time at which bees were sampled for diseases and parasites. Our results show that while

339 migratory conditions can negatively affect colony health and increase disease load, in some cases

340 these impacts were transient.

341 With the exception of Nosema, honey bee colonies experienced an increase in pathogen

342 prevalence and load over time with the highest levels occurring during the last sampling event in

343 March, following the seasonal trends of other time-course studies (Tentcheva et al., 2004;

344 Runckel et al., 2011). Peak incidences of these viruses occur in warmer months when

345 transmission is more likely to occur as a result of increased brood rearing (Chen \& Siede, 2007)

346 and increased foraging (Singh et al., 2010) However, for BQCV and Varroa, our results indicate

347 that bees in the migratory conditions were affected differently compared to their stationary

348 counterparts.

349 The migratory colonies in our study returned from almond pollination with higher BQCV

350 loads compared to the stationary colonies but had converged to similar levels one month later

351 indicating that migratory conditions exacerbated BQCV infection but these effects were

352 transient. Colonies experience stress during transportation (Simone-Finstrom et al., 2016) which

353 impairs immunity (James \& Xu, 2012) and promotes elevated levels of virus replication.

354 Pollinators of large monocultures experience a reduction in forage diversity (Decourtye, Mader

355 \& Desneux, 2010; Colwell et al., 2017) which increases susceptibility to disease (Di Pasquale et

356 al., 2013). Exposure to agricultural chemicals adversely affects the insect immune response and

357 promotes replication of RNA viruses in bees (Di Prisco et al., 2013; Doublet et al., 2015). In

358 particular, higher BQCV titers are associated with exposure to organosilicone surfactant

359 adjuvants (OSS), a class of surfactants used to enhance the spread of the active ingredient (Fine,

360 Cox-Foster \& Mullin, 2017). OSSs are heavily used in California almonds during the late 
361 January to March bloom period when migratory colonies are present (Ciarlo et al., 2012; Mullin

362 et al., 2016). In addition to OSSs, bees involved in almond pollination may also be exposed to a

363 wide range of pesticides. In recent years, the use of insecticides, herbicides, and fungicides has

364 steadily increased in California almond crops (CDPR (California Department of Pesticide

365 Regulation) CalPIP, 2016). We did not measure pesticide or OSS exposure in our colonies and

366 are therefore cautious to speculate its role in the increased virus loads in our study. However, in

367 light of our results and previous work, we believe pesticide-pathogen interactions in migratory

368 colonies warrants further study.

369 Compared to stationary colonies, the migratory colonies had fewer FOB upon return from

370 California. The lower population size observed may be a result of forager die-off after the large

371 pollination event, as migratory bees have significantly shorter lifespans when compared to

372 stationary bees as a result of increased oxidative stress (Simone-Finstrom et al., 2016). In

373 addition, foragers could have been displaced during transit. As typical with migratory colonies,

374 our colonies were moved to holding yards before and after pollinating almonds. When colonies

375 are moved, foragers are forced to re-assess and re-learn their surroundings which can cause

376 significant loss and/or drifting of foragers (Nelson \& Jay, 1989). Despite migratory colonies

377 returning with fewer numbers and remaining lower in FOB compared to stationary colonies, the

378 two groups experienced similar population growth rates during the month following the large

379 pollination event.

380 Upon return from California, mite prevalence and load in migratory colonies were similar

381 to their stationary counterparts. However, when sampled one month later, mite prevalence and

382 load in the stationary colonies had significantly increased, while mite prevalence and load in the

383 migratory colonies declined slightly, and was significantly lower than that in stationary colonies. 
384 Since female mites must reproduce within the pupal cells of developing honey bees, mite 385 population growth is largely dependent on the availability of bee brood. Although we did not 386 measure brood size, adult bee population size is highly correlated with brood size of the previous 387 time step (Torres, Ricoy \& Roybal, 2015) and mite population size (Martin, 1998; DeGrandi388 Hoffman et al., 2016). Thus, the lower mite prevalence and load in migratory bees is likely, in 389 part, a reflection of the lower reproduction of these colonies. Additional unknown factors may be 390 influencing the lower mite loads in migratory colonies, as Varroa loads of the migratory and 391 stationary colonies showed different relationships with FOB over time. Results of the US 392 National Honey Bee Disease survey suggested that migratory beekeepers may treat with 393 acaricide more effectively and the mechanical motion of the truck during transportation helps to 394 dislodge mites from bees (Traynor et al., 2016b). Since our colonies returned from California 395 with similar mite prevalence and load as the stationary group, it is unlikely that the motion of the 396 truck had an impact. Additionally, we are confident that the difference in mites we saw during 397 the last sampling event was not due to beekeeper practices as mite treatments were standardized 398 across all groups.

Colonies exposed to migratory bees experienced a significantly greater increase in DWV prevalence and load compared to isolated colonies one month after foraging alongside the migratory colonies. Varroa loads could not explain this difference since exposed and isolated 402 colonies experienced similar Varroa loads throughout the study. The greater population size of 403 the exposed colonies in the last sampling event, could have increased dissemination of DWV. 404 However, isolated colonies had higher bee populations than the migratory colonies and we saw 405 no differences in DWV prevalence or load between those two groups. Previous studies found 406 that DWV was a good predictor of weaker colonies (Budge et al., 2015) and thus one would not 
407 expect our results to simply be attributed to an increase in numbers and thus exposure. One

408 potential explanation is that the migratory bees returned from pollinating almonds with a more

409 virulent DWV strain that disseminated quickly in the exposed group as a result of their larger

410 colony size and higher Varroa population (Martin, 2002; Rosenkranz, Aumeier \& Ziegelmann,

411 2010; Glenny et al., 2017). Using deep sequencing, viruses not previously found in honey bees

412 have been detected in migratory hives (Runckel et al., 2011) and recently, a more virulent

413 recombinant of DWV was found to replicate at high levels when transmitted by Varroa mites

414 (Ryabov et al., 2014). Despite this evidence, we remain cautious of speculating transmission of a 415 novel or more virulent strain.

\section{Conclusions}

Migratory bees are subjected to a myriad of stressors not experienced by their stationary counterparts including transport, lower diversity of floral resources, exposure to bees from tens of thousands of other colonies that may be diseased, and exposure to large quantities of

420 pesticides. The migratory conditions in our experiment encompassed all these components, and

421 thus we cannot attribute our results to a single or even an exact combination of causes.

422 Furthermore, our study, while novel in scope, was conducted over a relatively short time span

423 using a single set of migratory conditions and focused on a limited set of bee pathogens. Thus,

424 we are cautious to claim that our results are representative of migratory beekeeping, at large, but

425 do suggest that migratory conditions may exacerbate BQCV infections and lead to slower colony

426 growth. Future studies to examine the underlying mechanisms, individually and in concert, as

427 well as those that encompass colony health and additional pest and pathogens over a longer time 428 span will provide further insight. 
A growing body of evidence suggests that pests and pathogens from managed bees are

430 spilling over into wild bee populations (Colla et al., 2006; Spiewok \& Neumann, 2006;

431 Hoffmann, Pettis \& Neumann, 2008; Otterstatter \& Thomson, 2008; Singh et al., 2010;

432 Graystock et al., 2013; Levitt et al., 2013; Brown, 2017). Sympatric bumble bees and honey bees

433 are infected by the same strains of DWV (Fürst et al., 2014) and virus prevalence in honey bees

434 is a significant predictor of virus prevalence in bumble bees (McMahon et al., 2015). The higher

435 BQCV load we document in migratory bees could thus pose a risk to wild bees. It is also

436 possible that increased disease load as a consequence of migratory pollination could affect honey

437 bees in future years due to disease spillback from infected wild bees (Graystock, Goulson \&

438 Hughes, 2015). Therefore, it is important to test whether wild bee populations have higher

439 disease prevalence in proximity to honey bee apiaries, particularly those with migratory

440 management practices.

441 According to recent forecasts, the US demand for commercial crop pollination services is 442 expected to rise, particularly for almond (USDA National Agricultural Statistics Service, 2017c).

443 Thus, understanding the effects of this current model of crop pollination on bees and identifying 444 where, when, and how to mitigate those effects are critical to the apiculture industry. Our work 445 suggests that some effects, while important, may be transitory. Thus, honey bees may be resilient 446 to some stressors imposed by migratory conditions and recuperation after large pollination events 447 is important to maintaining healthy migratory colonies.

\section{Acknowledgements}

449 We would like to thank Greer Sargeant and Kendall Eppley for their assistance in the laboratory, 450 and Jeff Lee for transporting the honey bee colonies across the country to California and back. 


\section{References}

453 Bakonyi T., Farkas R., Szendroi A., Dovos-Kovacs M., Rusvai M. 2002. Detection of acute bee

454 paralysis virus by RT-PCR in honey bee and Varroa destructor field samples: Rapid

455 screening of representative Hungarian apiaries. Apidologie 33:63-74. DOI: 10.1051/apido.

456 Bates D., Maechler M., Bolker B., Walker S. 2015. Fitting Linear Mixed-Effects Models Using

457 Ime4. Journal of Statistical Software 67:1-48. DOI: 10.18637/jss.v067.i01.

458 Beekman M., Ratnieks FLW. 2000. Long-range foraging by the honey-bee, Apis mellifera L.

$459 \quad$ Functional Ecol. 14:490-496.

460 Brodschneider R., Crailsheim K. 2010a. Nutrition and health in honey bees. Apidologie 41:278461294.

462 Brodschneider R., Crailsheim K. 2010b. Nutrition and health in honey bees. Apidologie 41:278-

463 294. DOI: $10.1051 /$ apido/2010012.

464 Brown MJF. 2017. Microsporidia: An Emerging Threat to Bumblebees? Trends in Parasitology

465 33:754-762. DOI: 10.1016/j.pt.2017.06.001.

466 Budge GE., Pietravalle S., Brown M., Laurenson L., Jones B., Tomkies V., Delaplane KS. 2015.

467 Pathogens as predictors of honey bee colony strength in England and Wales. PLoS ONE

468 10:e0133228. DOI: 10.1371/journal.pone.0133228.

469 Calderone NW. 2012. Insect pollinated crops, insect pollinators and US agriculture: trend

470 analysis of aggregate data for the period 1992-2009. PLoS One 7:e37235. DOI:

$471 \quad$ 10.1371/journal.pone.0037235.

472 California Department of Pesticide Regulation. 2017. Summary of Pesticide Use Report Data $473 \quad 2015$ Indexed by Commodity.

474 Carman H. 2011. The Estimated Impact of Bee Colony Collapse Disorder on Almond Pollination 
$475 \quad$ Fees.

476 CDPR (California Department of Pesticide Regulation) CalPIP. 2016. California Pesticide

477 Information Portal. Available at: http://calpip. cdpr.ca.gov/main.cfm.

478 Chen Y., Evans JD., Smith IB., Pettis JS. 2008. Nosema ceranae is a long-present and wide-

479 spread microsporidian infection of the European honey bee (Apis mellifera) in the United

480 States. Journal of Invertebrate Pathology 97:186-188. DOI: 10.1016/j.jip.2007.07.010.

481 Chen Y., Siede R. 2007. Honey Bee Viruses. Advances in Virus Research 70:33-80. DOI:

$482 \quad 10.1016 / \mathrm{S} 0065-3527(07) 70002-7$.

483 Ciarlo TJ., Mullin CA., Frazier JL., Schmehl DR. 2012. Learning impairment in honey bees

484 caused by agricultural spray adjuvants. PLoS ONE 7. DOI: 10.1371/journal.pone.0040848.

485 Colla SR., Otterstatter MC., Gegear RJ., Thomson JD. 2006. Plight of the bumble bee: Pathogen

486 spillover from commercial to wild populations. Biological Conservation 129:461-467.

487 DOI: $10.1016 /$ j.biocon.2005.11.013.

488 Colwell MJ., Williams GR., Evans RC., Shutler D. 2017. Honey bee-collected pollen in agro-

489 ecosystems reveals diet diversity, diet quality, and pesticide exposure. Ecology and

490 Evolution 7:7243-7253. DOI: 10.1002/ece3.3178.

491 Couvillon MJ., Riddell Pearce FC., Accleton C., Fensome KA., Quah SKL., Taylor EL.,

492 Ratnieks FLW. 2015. Honey bee foraging distance depends on month and forage type.

493 Apidologie 46:61-70. DOI: 10.1007/s13592-014-0302-5.

494 Decourtye A., Mader E., Desneux N. 2010. Landscape enhancement of floral resources for

495 honey bees in agro-ecosystems. Apidologie 41:264-277. DOI: 10.1051/apido/2010024.

496 DeGrandi-Hoffman G., Ahumada F., Zazueta V., Chambers M., Hidalgo G., DeJong EW. 2016.

497 Population growth of Varroa destructor (Acari: Varroidae) in honey bee colonies is affected 
by the number of foragers with mites. Experimental and Applied Acarology 69:21-34. DOI: 10.1007/s10493-016-0022-9.

Doublet V., Labarussias M., de Miranda JR., Moritz RFA., Paxton RJ. 2015. Bees under stress: Sublethal doses of a neonicotinoid pesticide and pathogens interact to elevate honey bee mortality across the life cycle. Environmental Microbiology 17:969-983. DOI:

504 $10.1111 / 1462-2920.12426$.

Evans JD. 2006. Protocol and budget for real-time PCR diagnostics for honey bees.

505

506

507

508

509

510

511

512

513

514

515

516

517

518

519

520

Fine JD., Cox-Foster DL., Mullin CA. 2017. An inert pesticide adjuvant synergizes viral pathogenicity and mortality in honey bee larvae. Scientific Reports 7:1-9. DOI: $10.1038 /$ srep40499.

Fox J., Weisberg S. 2011. An $\{\mathrm{R}\}$ Companion to Applied Regression, Second Edition.

Fries I., Chauzat M-P., Chen Y-P., Doublet V., Genersch E., Gisder S., Higes M., McMahon DP., Martín-Hernández R., Natsopoulou M., Paxton RJ., Tanner G., Webster TC., Williams GR. 2013. Standard methods for Nosema research. Journal of Apicultural Research 52:128. DOI: 10.3896/IBRA.1.52.1.14.

Fürst M a., McMahon DP., Osborne JL., Paxton RJ., Brown MJF. 2014. Disease associations between honeybees and bumblebees as a threat to wild pollinators. Nature 506:364-6. DOI: 10.1038 /nature 12977.

Gallai N., Salles JM., Settele J., Vaissière BE. 2009. Economic valuation of the vulnerability of world agriculture confronted with pollinator decline. Ecological Economics 68:810-821. DOI: 10.1016/j.ecolecon.2008.06.014.

Glenny W., Cavigli I., Daughenbaugh KF., Radford R., Kegley SE., Flenniken ML. 2017. Honey bee (Apis mellifera) colony health and pathogen composition in migratory beekeeping 
521 operations involved in California almond pollination. PLoS ONE 12:e0182814. DOI:

$522 \quad$ 10.1371/journal.pone.0182814.

523 Goulson D., Nicholls E., Botias C., Rotheray EL. 2015. Bee declines driven by combined stress

524 from parasites, pesticides, and lack of flowers. Science 347:1255957-1-1255957-9. DOI:

$525 \quad 10.1126 /$ science. 1255957.

526 Graystock P., Goulson D., Hughes WOH. 2015. Parasites in bloom : flowers aid dispersal and

527 transmission of pollinator parasites within and between bee species. Proceedings of the

$528 \quad$ Royal Society B: Biological Sciences 282.

529 Graystock P., Yates K., Darvill B., Goulson D., Hughes WOH. 2013. Emerging dangers: Deadly

530 effects of an emergent parasite in a new pollinator host. Journal of Invertebrate Pathology

$531 \quad$ 114:114-119. DOI: 10.1016/j.jip.2013.06.005.

532 Harrison XA., Donaldson L., Correa-Cano ME., Evans J., Fisher DN., Goodwin CED., Robinson

533 BS., Hodgson DJ., Inger R. 2018. A brief introduction to mixed effects modelling and

534 multi-model inference in ecology. PeerJ 6:e4794. DOI: 10.7717/peerj.4794.

535 Higes M., Martín-Hernández R., Botías C., Bailón EG., González-Porto A V., Barrios L., Del

536 Nozal MJ., Bernal JL., Jiménez JJ., Palencia PG., Meana A. 2008. How natural infection by

537 Nosema ceranae causes honeybee colony collapse. Environmental Microbiology 10:2659-

538 2669. DOI: $10.1111 / \mathrm{j} .1462-2920.2008 .01687 . x$.

539 Hoffmann D., Pettis JS., Neumann P. 2008. Potential host shift of the small hive beetle (Aethina

540 tumida) to bumblebee colonies (Bombus impatiens). Insectes Sociaux 55:153-162. DOI:

$541 \quad 10.1007 / \mathrm{s} 00040-008-0982-9$.

542 Huang Z. 2012. Pollen nutrition affects honey bee stress resistance. Terrestrial Arthropod

543 Reviews 5:175-189. DOI: 10.1163/187498312X639568. 
544 James RR., Xu J. 2012. Mechanisms by which pesticides affect insect immunity. Journal of 545 Invertebrate Pathology 109:175-182. DOI: 10.1016/j.jip.2011.12.005.

546 Kevan PG., Ebert T. 2005. Can almond nectar and pollen poison honey bees? American Bee 547 Journal 145:507-510. DOI: 10.1080/19440049.2010.541594.

548 Klee J., Besana AM., Genersch E., Gisder S., Nanetti A., Tam DQ., Chinh TX., Puerta F., Ruz

549 JM., Kryger P., Message D., Hatjina F., Korpela S., Fries I., Paxton RJ. 2007. Widespread 550 dispersal of the microsporidian Nosema ceranae, an emergent pathogen of the western 551 honey bee, Apis mellifera. Journal of Invertebrate Pathology 96:1-10. DOI:

$552 \quad$ 10.1016/j.jip.2007.02.014.

553 Klein A-M., Vaissière BE., Cane JH., Steffan-Dewenter I., Cunningham SA., Kremen C., 554 Tscharntke T. 2007. Importance of pollinators in changing landscapes for world crops. 555 Proceedings of the Royal Society B: Biological Sciences 274:303-313. DOI:

$556 \quad 10.1098 / \mathrm{rspb} .2006 .3721$.

557 Kulhanek K., Steinhauer N., Rennich K., Caron DM., Sagili R., Pettis JS., Ellis JD., Wilson ME., 558 Wilkes JT., Tarpy DR., Rose R., Lee K., Rangel J., VanEngelsdorp D. 2017. A national 559 survey of managed honey bee 2015-2016 annual colony losses in the USA. Journal of $560 \quad$ Apicultural Research 56:328-340. DOI: 10.1007/s13592-015-0356-z.

561 Lee K V., Moon RD., Burkness EC., Hutchison WD., Spivak M. 2010. Practical Sampling Plans 562 for Varroa destructor (Acari: Varroidae) in Apis mellifera (Hymenoptera: Apidae) Colonies 563 and Apiaries. Journal of economic entomology 103:1039-1050. DOI: 10.1603/EC10037.

564 Levitt AL., Singh R., Cox-Foster DL., Rajotte E., Hoover K., Ostiguy N., Holmes EC. 2013. 565 Cross-species transmission of honey bee viruses in associated arthropods. Virus Research 566 176:232-240. DOI: 10.1016/j.virusres.2013.06.013. 
567 London-Shafir I., Shafir S., Eisikowitch D. 2003. Amygdalin in almond nectar and pollen - facts

568 and possible roles. Plant Systematics \& Evolution 238:87-95. DOI: 10.1007/s00606-003-

$569 \quad 0272-y$.

570 Martin S. 1998. A population model for the ectoparasitic mite Varroa jacobsoni in honey bee

571 (Apis mellifera) colonies. Ecological Modelling 109:267-281. DOI: 10.1016/S0304-

$572 \quad 3800(98) 00059-3$.

573 Martin SJ. 2002. The role of Varroa and viral pathogens in the collapse of honeybee colonies: a

$574 \quad$ modelling approach. Journal of Applied Ecology 38:1082-1093.

575 McMahon DP., Fürst M a., Caspar J., Theodorou P., Brown MJF., Paxton RJ. 2015. A sting in

576 the spit: widespread cross-infection of multiple RNA viruses across wild and managed bees.

577 Journal of Animal Ecology 84:615-624. DOI: 10.1111/1365-2656.12345.

578 Mullin CA., Fine JD., Reynolds RD., Frazier MT. 2016. Toxicological Risks of Agrochemical

579 Spray Adjuvants: Organosilicone Surfactants May Not Be Safe. Frontiers in Public Health

580 4:1-8. DOI: $10.3389 /$ fpubh.2016.00092.

581 Mullin CA., Frazier M., Frazier JL., Ashcraft S., Simonds R., Vanengelsdorp D., Pettis JS. 2010.

582 High levels of miticides and agrochemicals in North American apiaries: implications for

583 honey bee health. PloS one 5:e9754. DOI: 10.1371/journal.pone.0009754.

584 Nazzi F., Brown SP., Annoscia D., Del Piccolo F., Di Prisco G., Varricchio P., Vedova G Della.,

585 Cattonaro F., Caprio E., Pennacchio F. 2012. Synergistic parasite-pathogen interactions

586 mediated by host immunity can drive the collapse of honeybee colonies. PLoS Pathogens 8.

587 DOI: 10.1371/journal.ppat.1002735.

588 Nelson D., Jay S. 1989. The effect of colony relocation on loss and disorientation of honeybees.

589 Apidologie 20:245-250. 
590 Neumann P., Carreck NL. 2010. Honey bee colony losses. Journal of Apicultural Research 591 49:1-6. DOI: 10.3896/IBRA.1.49.1.01.

592 Oksanen J., Blanchet FG., Friendly M., Roeland K., Legendre P., McGlinn D., Minchin PR., R.

593 B. O., Simpson GL., Solymos P., Stevens MHH., Szoecs E., Wagner H. 2017. vegan:

$594 \quad$ Community Ecology Package.

595 Otterstatter MC., Thomson JD. 2008. Does pathogen spillover from commercially reared bumble 596 bees threaten wild pollinators? PLoS ONE 3. DOI: 10.1371/journal.pone.0002771.

597 Di Pasquale G., Salignon M., Le Conte Y., Belzunces LP., Decourtye A., Kretzschmar A., 598 Suchail S., Brunet JL., Alaux C. 2013. Influence of Pollen Nutrition on Honey Bee Health: 599 Do Pollen Quality and Diversity Matter? PLoS ONE 8:e72016. DOI:

$600 \quad$ 10.1371/journal.pone.0072016.

601 Potts SG., Biesmeijer JC., Kremen C., Neumann P., Schweiger O., Kunin WE. 2010. Global 602 pollinator declines: Trends, impacts and drivers. Trends in Ecology and Evolution 25:345603 353. DOI: $10.1016 /$ j.tree.2010.01.007.

604 Di Prisco G., Cavaliere V., Annoscia D., Varricchio P., Caprio E., Nazzi F. 2013. Neonicotinoid 605 clothianidin adversely affects insect immunity and promotes replication of a viral pathogen 606 in honey bees. Proceedings of the National Academy of Sciences 110:18466-18471. DOI: $607 \quad 10.1073 /$ pnas. 1314923110.

608 Ripley WN., Venables BD. 2002. Modern Applied Statistics with S. New York: Springer.

609 Rosenkranz P., Aumeier P., Ziegelmann B. 2010. Biology and control of Varroa destructor. 610 Journal of Invertebrate Pathology 103:S96-S119. DOI: 10.1016/j.jip.2009.07.016.

611 Royce LA., Rossignol PA. 1990. Epidemiology of honey bee parasites. Parasitology Today $612 \quad 6: 348-353$. 
613 Runckel C., Flenniken ML., Engel JC., Ruby JG., Ganem D., Andino R., DeRisi JL. 2011.

614 Temporal analysis of the honey bee microbiome reveals four novel viruses and seasonal

615 prevalence of known viruses, Nosema, and Crithidia. PloS one 6:e20656. DOI:

$616 \quad$ 10.1371/journal.pone.0020656.

617 Ryabov E V., Wood GR., Fannon JM., Moore JD., Bull JC., Chandler D., Mead A., Burroughs

618 N., Evans DJ. 2014. A Virulent Strain of Deformed Wing Virus (DWV) of Honeybees

619 (Apis mellifera) Prevails after Varroa destructor-Mediated, or In Vitro, Transmission. PLoS

620 Pathogens 10:e1004230. DOI: 10.1371/journal.ppat.1004230.

621 Sánchez-Bayo F., Goulson D., Pennacchio F., Nazzi F., Goka K., Desneux N. 2016. Are bee

622 diseases linked to pesticides? - A brief review. Environment International 89-90:7-11.

623 DOI: 10.1016/j.envint.2016.01.009.

624 Simone-Finstrom M., Li-Byarlay H., Huang MH., Strand MK., Rueppell O., Tarpy DR. 2016.

625 Migratory management and environmental conditions affect lifespan and oxidative stress in 626 honey bees. Scientific Reports 6:32023. DOI: 10.1038/srep32023.

627 Singh R., Levitt AL., Rajotte EG., Holmes EC., Ostiguy N., Vanengelsdorp D., Lipkin WI.,

628 Depamphilis CW., Toth AL., Cox-Foster DL. 2010. RNA viruses in hymenopteran

629 pollinators: Evidence of inter-taxa virus transmission via pollen and potential impact on

630 non-Apis hymenopteran species. PLoS ONE 5:e14357. DOI:

$631 \quad$ 10.1371/journal.pone.0014357.

632 Spiewok S., Neumann P. 2006. Infestation of commercial bumblebee (Bombus impatiens) field 633 colonies by small hive beetles (Aethina tumida). Ecological Entomology 31:623-628. DOI: $634 \quad 10.1111 / \mathrm{j} .1365-2311.2006 .00827 . x$.

635 Tentcheva D., Gauthier L., Zappulla N., Dainat B., Cousserans F., Colin ME., Bergoin M. 2004. 
636 Prevalence and seasonal variations of six bee viruses in Apis mellifera L. and Varroa

637 destructor mite populations in France. Applied and Environmental Microbiology 70:7185-

638 7191. DOI: 10.1128/AEM.70.12.7185-7191.2004.

639 Torres DJ., Ricoy UM., Roybal S. 2015. Modeling Honey Bee Populations. PLoS ONE 10. DOI:

$640 \quad$ 10.1371/journal.pone.0130966.

641 Traynor KS., Pettis JS., Tarpy DR., Mullin CA., Frazier JL., Frazier M., VanEngelsdorp D.

642 2016a. In-hive Pesticide Exposome: Assessing risks to migratory honey bees from in-hive

643 pesticide contamination in the Eastern United States. Scientific Reports 6:1-16. DOI:

$644 \quad 10.1038 /$ srep33207.

645 Traynor KS., Rennich K., Forsgren E., Rose R., Pettis J., Kunkel G., Madella S., Evans J., Lopez

646 D., VanEngelsdorp D. 2016b. Multiyear survey targeting disease incidence in US honey

647 bees. Apidologie 47:325-347. DOI: 10.1007/s13592-016-0431-0.

648 Tsvetkov N., Samson-Robert O., Sood K., Patel HS., Malena DA., Gajiwala PH., Maciukiewicz

649 P., Fournier V., Zayed A. 2017. Chronic exposure to neonicotinoids reduces honey bee

650 health near corn crops. Science 356:1395-1397. DOI: 10.1126/science.aam7470.

651 USDA National Agricultural Statistics Service. 2017b. Honey Bee Colonies.

652 USDA National Agricultural Statistics Service. 2017a. Cost of Pollination. :1-13.

653 USDA National Agricultural Statistics Service. 2017c. 2017 California Almond Forecast.

654 vanEngelsdorp D., Meixner MD. 2010. A historical review of managed honey bee populations in

655 Europe and the United States and the factors that may affect them. Journal of Invertebrate

656 Pathology 103:S80-S95. DOI: 10.1016/j.jip.2009.06.011.

657 VanEngelsdorp D., Tarpy DR., Lengerich EJ., Pettis JS. 2013. Idiopathic brood disease

658 syndrome and queen events as precursors of colony mortality in migratory beekeeping 
operations in the eastern United States. Preventive Veterinary Medicine 108:225-233. DOI:

660 10.1016/j.prevetmed.2012.08.004.

661 Visscher KP., Seeley TD. 1982. Foraging Strategy of Honeybee Colonies in a Temperate 662 Deciduous Forest. Ecology 63:1790-1801.

663 Welch A., Drummond F., Tewari S., Averill A., Burand JP. 2009. Presence and prevalence of 664 viruses in local and migratory honeybees (Apis mellifera) in Massachusetts. Applied and 665 Environmental Microbiology 75:7862-7865. DOI: 10.1128/AEM.01319-09.

Williams GR., Sampson MA., Shutler D., Rogers REL. 2008. Does fumagillin control the recently detected invasive parasite Nosema ceranae in western honey bees (Apis mellifera)? Journal of Invertebrate Pathology 99:342-344. DOI: 10.1016/j.jip.2008.04.005.

Williams GR., Shutler D., Burgher-MacLellan KL., Rogers REL. 2014. Infra-population and 670 community dynamics of the parasites Nosema apis and Nosema ceranae, and consequences for honey bee (Apis mellifera) hosts. PLoS ONE 9:5-10. DOI:

672 10.1371/journal.pone.0099465.

673 Woodcock BA., Bullock JM., Shore RF., Heard MS., Pereira MG., Redhead J., Ridding L., Dean 674 H., Sleep D., Henrys P., Peyton J., Hulmes S., Hulmes L., Sárospataki M., Saure C., 675 Edwards M., Genersch E., Knäbe S., Pywell RF. 2017. Country-specific effects of 676 neonicotinoid pesticides on honey bees and wild bees. Science 356:1393-1395. DOI: 10.1126/science.aaa1190.

Yates WD. 1982. A review of infectious bovine rhinotracheitis, shipping fever pneumonia and 679 viral-bacterial synergism in respiratory disease of cattle. Canadian journal of comparative 680 medicine 46:225-263.

681 van der Zee R., Gray A., Holzmann C., Pisa L., Brodschneider R., Chlebo R., Coffey MF., 
682

683

684

685

686

687

688

689

690

691

692

693

694

695

696

Kence A., Kristiansen P., Mutinelli F., Nguyen BK., Noureddine A., Peterson M., Soroker V., Topolska G., Vejsnæs F., Wilkins S. 2013. Standard survey methods for estimating colony losses and explanatory risk factors in Apis mellifera. Journal of Apicultural Research 52:1-36. DOI: 10.3896/IBRA.1.52.4.18.

van der Zee R., Pisa L., Andonov S., Brodschneider R., Charrière J-D., Chlebo R., Coffey MF., Crailsheim K., Dahle B., Gajda A., Gray A., Drazic MM., Higes M., Kauko L., Kence A., Kence M., Kezic N., Kiprijanovska H., Kralj J., Kristiansen P., Hernandez RM., Mutinelli F., Nguyen BK., Otten C., Özkırım A., Pernal SF., Peterson M., Ramsay G., Santrac V., Soroker V., Topolska G., Uzunov A., Vejsnæs F., Wei S., Wilkins S. 2012. Managed honey bee colony losses in Canada, China, Europe, Israel and Turkey, for the winters of 2008-9 and 2009-10. Journal of Apicultural Research 51:100-114. DOI: 10.3896/IBRA.1.51.1.12. Zhu X., Zhou S., Huang ZY. 2014. Transportation and pollination service increase abundance and prevalence of Nosema ceranae in honey bees ( Apis mellifera ). Journal of Apicultural Research 53:469-471. DOI: 10.3896/IBRA.1.53.4.06. 


\section{Figure 1}

\section{Schematic of Experimental Design}

Three sampling events occurred during the experiment. Three experimental groups (isolated stationary group, migratory group, and exposed group) were located in two separate apiaries in North Carolina throughout the experiment: the stationary yard (where all groups begin and the isolated stationary group remained for the duration of the experiment) and the exposed yard (where the exposed group was exposed to the migratory group). Dotted arrows show movement of colonies throughout the experiment. Between sampling events one and two, the migratory colonies were transported to California for almond pollination and back. Exposed colonies began in the stationary yard and were transferred to the exposed yard prior to sampling event two. Geographic distance between yards are specified in kilometers.

\section{Sampling Event 1}

(when migratory group returned)

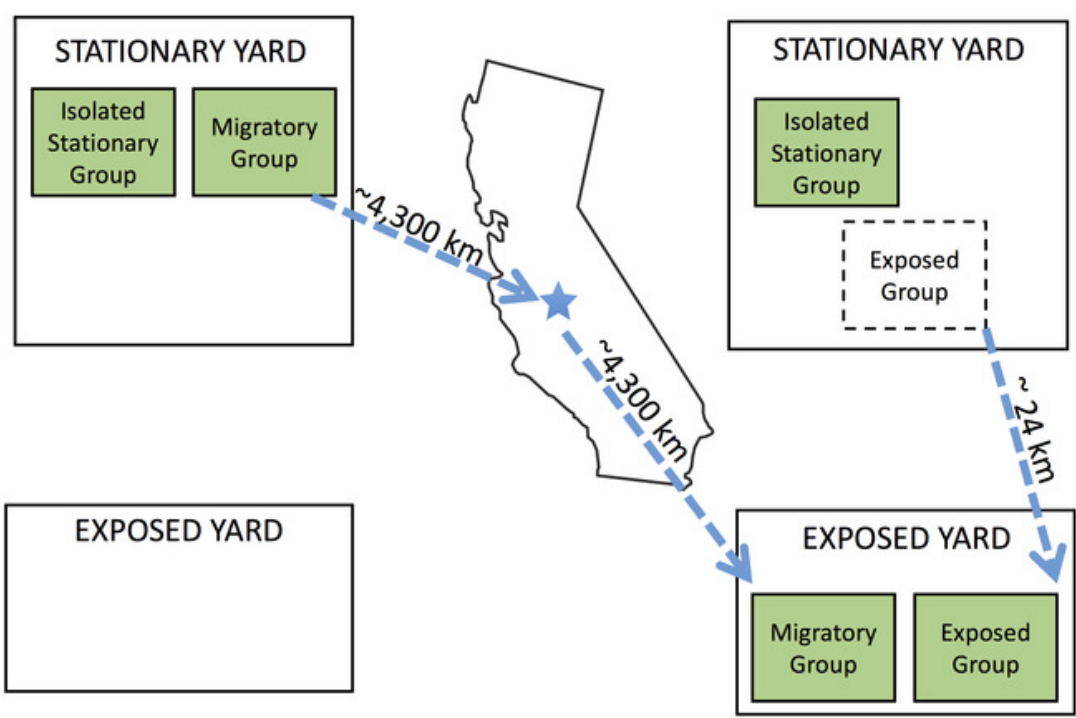

Sampling Event 3 (after 1 month exposure)

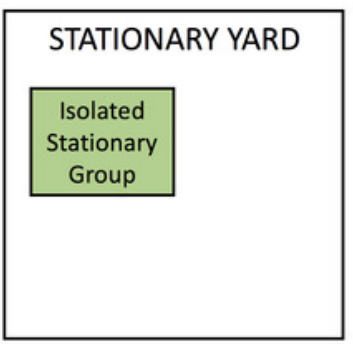

EXPOSED YARD

Migratory Group 


\section{Figure 2}

Pathogen community and colony health predicts treatment group membership

Linear combinations from discriminant analyses created from all pathogen variables (except BQCV prevalence) and frames of bees for exposed (black), migratory (red) and stationary/isolated (blue) colonies. Axes represent the percentage of between group variance explained.(A) Experiment 1 at sampling event two, migratory and stationary colonies were separated by LD1 while stationary and exposed colonies are clustered. B)Experiment 2 at sampling event three, after the exposed group had been allowed to forage alongside the migratory colonies, exposed and isolated were separated along LD2, while LD1 separated out migratory colonies. The significant PERMANOVA tests for both experiments corroborated the differences between group centroids. Circles represent $70 \%$ confidence intervals and are provided to visualize the centroids of each group.
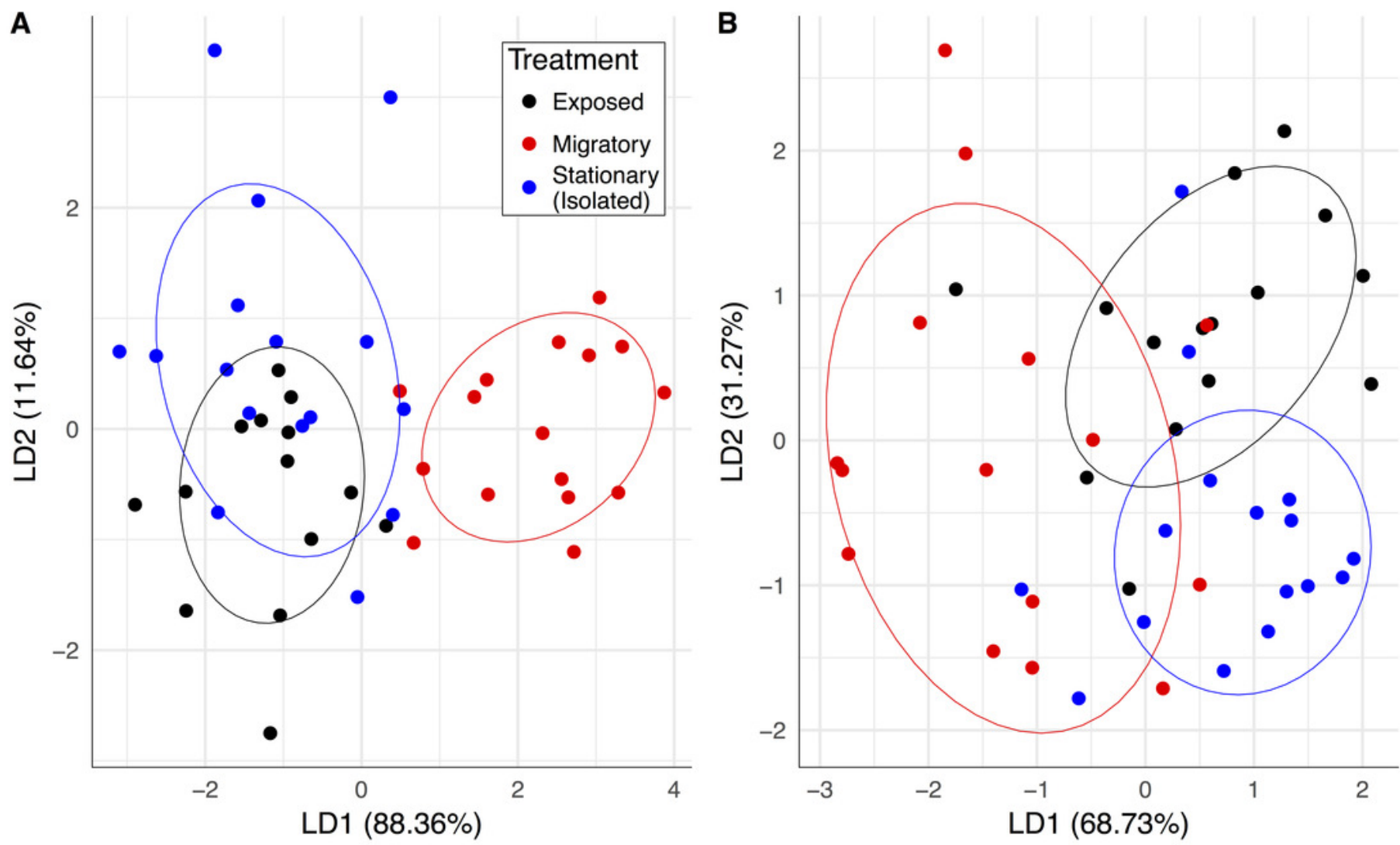


\section{Figure 3}

Pathogen and colony population metrics for treatment groups through time

Migratory (solid line) and stationary/isolated (dotted line) colonies were sampled at three time points and exposed (gray) colonies were sampled at two time points. Sampling event (1) occurred before migratory colonies were transported, (2) upon their return, and (3) one month after return. Panels show results for three pathogens and one health metric: $(A)$ black queen cell virus (BQCV) in log genome copies per bee (B) deformed wing virus (DWV) in log genome copies per bee (C) Varroa load in mites per 100 bees and (D) Frames of bees (FOB), as a proxy for colony population. In Experiment 1: migratory verses stationary/isolated colonies, there was a significant effect of time for all measures. For BQCV, there was a significant effect of treatment. There was a significant time $\times$ treatment interaction for FOB and Varroa. In Experiment 2: exposed colonies verses stationary/isolated, there was a significant effect of time for each measure. For DWV, there was a significant time $\times$ treatment interaction. Bars represent standard errors. 

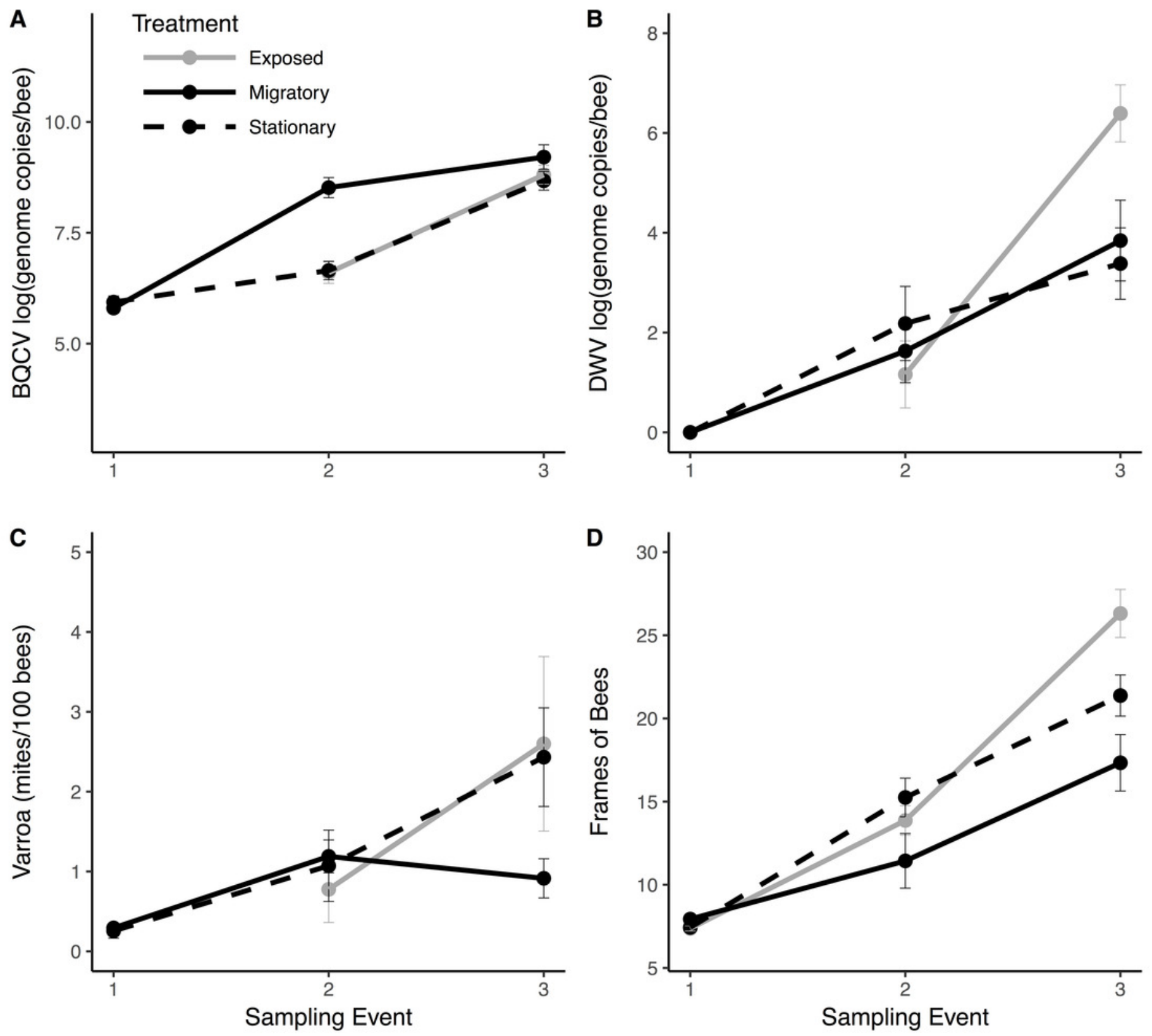


\section{Table $\mathbf{1}$ (on next page)}

Summary statistics for experiment 1: migratory verses stationary

DWV load, deformed wing virus load; DWV prev., deformed wing virus prevalence; BQCV load, black queen cell virus load; Varroa prev., Varroa prevalence; Nosema prev., Nosema prevalence; FOB, frames of bees. Prevalence is the percentage of colonies positive for a pathogen (DWV, Nosema, and Varroa). Virus load (DWV and BQCV) results for each colony are presented in average virus genome copies/bee. Nosema load is reported as average number of spores/bee and Varroa is reported as number of mites per 100 bees. 


\begin{tabular}{|c|c|c|c|c|}
\hline Variable & Effect & $\chi_{1}^{2}$ & $\mathbf{P}^{\mathbf{a}}$ & Sigb \\
\hline \multirow[t]{3}{*}{ DWV load } & Treatment & 0.004 & 0.9512 & \\
\hline & Time & 39.328 & $<0.001$ & $* * *$ \\
\hline & Treatment:Time & 0.1592 & 0.690 & \\
\hline \multirow[t]{3}{*}{ DWV prev. } & Treatment & 0.067 & 0.796 & \\
\hline & Time & 15.805 & $<0.001$ & $* * *$ \\
\hline & Treatment:Time & 0.024 & 0.878 & \\
\hline \multirow[t]{3}{*}{ BQCV load } & Treatment & 16.488 & $<0.001$ & $* * *$ \\
\hline & Time & 187.235 & $<0.001$ & $* * *$ \\
\hline & Treatment:Time & 2.229 & 0.135 & \\
\hline \multirow[t]{3}{*}{ Varroa load } & Treatment & 0.413 & 0.520 & \\
\hline & Time & 18.391 & $<0.001$ & $* * *$ \\
\hline & Treatment:Time & 6.465 & 0.011 & $*$ \\
\hline \multirow[t]{3}{*}{ Varroa prev. } & Treatment & 1.290 & 0.256 & \\
\hline & Time & 4.896 & 0.0270 & $*$ \\
\hline & Treatment:Time & 3.21 & 0.073 & \\
\hline \multirow[t]{3}{*}{ Nosema load } & Treatment & 0.645 & 0.422 & \\
\hline & Time & 30.855 & $<0.001$ & $* * *$ \\
\hline & Treatment:Time & 0.280 & 0.596 & \\
\hline \multirow[t]{3}{*}{ Nosema prev. } & Treatment & 0.007 & 0.931 & \\
\hline & Time & 3.652 & 0.056 & \\
\hline & Treatment:Time & 3.352 & 0.067 & \\
\hline \multirow[t]{3}{*}{ FOB } & Treatment & 3.597 & 0.058 & \\
\hline & Time & 152.838 & $<0.001$ & $* * *$ \\
\hline & Treatment:Time & 5.651 & 0.0174 & $*$ \\
\hline
\end{tabular}

2

3 a Significance for all models was determined using Type II Wald Chi-Square tests.

4 bAsterisks represent level of significance. 


\section{Table 2 (on next page)}

Summary statistics for experiment 2: exposed verses isolated

DWV load, deformed wing virus load; DWV prev., deformed wing virus prevalence; BQCV load, black queen cell virus load; Varroa prev., Varroa prevalence; Nosema prev., Nosema prevalence; FOB, frames of bees. Prevalence is the percentage of colonies positive for a pathogen (DWV, Nosema, and Varroa). Virus load (DWV and BQCV) results for each colony are presented in average virus genome copies/bee. Nosema load is reported as average number of spores/bee and Varroa is reported as number of mites per 100 bees. 


\begin{tabular}{|c|c|c|c|c|}
\hline Variable & Effect & $\chi_{1}^{2}$ & $\mathbf{P}^{\mathbf{a}}$ & Sig.b \\
\hline \multirow[t]{3}{*}{ DWV load } & Treatment & 2.056 & 0.152 & \\
\hline & Time & 23.510 & $<0.001$ & $* * *$ \\
\hline & Treatment:Time & 9.229 & 0.002 & $* *$ \\
\hline \multirow[t]{3}{*}{ DWV prev. } & Treatment & 0.025 & 0.874 & \\
\hline & Time & 8.811 & 0.003 & $* *$ \\
\hline & Treatment:Time & 4.945 & 0.026 & $*$ \\
\hline \multirow[t]{3}{*}{ BQCV load } & Treatment & 1.355 & 0.244 & \\
\hline & Time & 58.001 & $<0.001$ & $* * *$ \\
\hline & Treatment:Time & 0.054 & 0.816 & \\
\hline \multirow[t]{3}{*}{ Varroa load } & Treatment & 0.471 & 0.493 & \\
\hline & Time & 23.658 & $<0.001$ & $* * *$ \\
\hline & Treatment:Time & 0.191 & 0.662 & \\
\hline \multirow[t]{3}{*}{ Varroa prev. } & Treatment & 1.390 & 0.238 & \\
\hline & Time & 10.129 & 0.001 & $* *$ \\
\hline & Treatment:Time & 0.060 & 0.806 & \\
\hline \multirow[t]{3}{*}{ Nosema load } & Treatment & 0.882 & 0.348 & \\
\hline & Time & 37.926 & $<0.001$ & $* * *$ \\
\hline & Treatment:Time & 0.260 & 0.610 & \\
\hline \multirow[t]{3}{*}{ Nosema prev. } & Treatment & 0 & 0.1 & \\
\hline & Time & 7.771 & 0.005 & $* *$ \\
\hline & Treatment:Time & 0.004 & 0.950 & \\
\hline \multirow[t]{3}{*}{ FOB } & Treatment & 1.899 & 0.168 & \\
\hline & Time & 89.191 & $<0.001$ & $* * *$ \\
\hline & Treatment:Time & 9.946 & 0.002 & $* *$ \\
\hline
\end{tabular}

2

3 a Significance for all models was determined using Type II Wald Chi-Square tests.

$4 \quad$ b Asterisks represent level of significance. 